\title{
Hate Speech in Nigeria and Its Implication for National Cohesion
}

\author{
Okpara Onyekwere \\ Department of Languages and Communication \\ Abia State Polytechnic, Aba \\ Chukwu Ebere Mercy \\ Department of Languages and Communication \\ Abia State Polytechnic, Aba
}

\begin{abstract}
This paper investigates the use of hate speech in Nigeria. Data for the study were collected through questionnaire distribution. The population for the study was randomly drawn from academic staff, non-academic staff and students of Abia State Polytechnic, Aba, Nigeria. Results from data analysis reveal that majority of the respondents were aware of the use of hate speech in Nigeria and its negative consequences. Over $70 \%$ of the respondents indicated that economic hardship, maginalisation and the desire to demean and outwit others are among the reasons people use hate speech. Below $60 \%$ of the respondents indicated that hate speech has no effect on national unity/cohesion while over $60 \%$ of them said it could result in violence and under-development. Based on the above, the paper concludes that hate speech is a threat to national cohesion and development and therefore should be managed effectively.
\end{abstract}

\section{Introduction}

Language is a social phenomenon. Language is not acquired or learnt for its form's sake but is used to perform diverse communicative and social functions such as expressing opinion, feeling, or desires, asking questions, phatic communion, making suggestions, reacting to positive and negative actions, giving commands, inciting or persuading others, condemning and commending actions, etc. Saeed (2003, p.219) notes that the language user needs to "learn the uses to which utterances are conventionally put in the ... language and how these uses are signaled." This also means that as the learner/user is learning to use language, the hearer should be able to understand the communicative reality of utterances so as to know when he is being asked questions, abused, persuaded or otherwise (Saeed, 2003, p.219). The above phenomenon is what is technically known as Speech Act. In evaluating performative utterances, Saeed (2003) further observes that Speech Act may be successful or unsuccessful, may misfire or be abused. For detailed information on evaluating speech acts, see Saeed (2003, pp. 220-231).

Hate speech is an aspect of Speech Act. It is one of the ways language is construed or put to use. Özarslan (2014) proposes that hate speech should be conceptualized as Speech Act or discourse and be named "Hate Speech Act". This is based on the fact that hate speech reflects socio-cultural realities of language; as an "act", it is 'doing something' on the victims which sometimes results in violence and or psychological trauma. Down (2012) observes that hate speech is a dangerous weapon which is capable of terrorizing a person or group of people. In Nigeria, it is viewed as being capable of inciting war, causing ethnic clashes and territorial disputes or civil war (The Guardian, 2018). In 2017, the Nigerian government pronounced hate speech as an act of terrorism which results in the Senate proposing some bills on hate speech. It has also been observed that hate speech including its negative consequences is among the indicators of disunity and segregation (Ozarslan 2014). It is based on the above that this paper investigates the level of hate speech awareness among Abia State Polytechnic, Aba staff (academic and non-academic) and students and the effort being made by the Nigerian government to sensitise the citizens on what constitutes hate speech, its effects and possible ways of controlling or managing it so as to reduce negative incidences of hate speech in Nigeria.

\section{Objectives of the study}

The objectives of the study include to

i. ascertain perception of hate speech and level of awareness on what constitutes hate speech in Nigeria by Abia State Polytechnic, Aba staff and students;

ii. determine why people use hate speech in Nigeria and the people's perception of hate speech laws; and

iii. to determine the effect of hate speech on national cohesion 


\section{Research Questions}

This study is guided by the following questions:

i. What is the perception of the Abia State Polytechnic, Aba staff and students of hate speech in Nigeria?

ii. Why do people use hate speech in Nigeria and what are the perceptions of the respondents of hate speech laws?

iii. What are the effects of hate speech on national cohesion?

\section{Statement of Research Problem}

In 2017, the Nigerian government pronounced hate speech as an act of terrorism capable of causing civil war or social unrest or psychological trauma. The bill before the senate states that "any person found guilty of any form of hate speech that results in the death of another or stirs up ethnic hatred shall die by hanging (The Guardian, 2018). In addition to the above, the senate is also considering establishing a commission "The Commission for Hate Speech" which among its duties includes to sensitise citizens on the effects of and laws guiding hate speech; to receive and attend to complaints relating to hate speech, etc. There is, therefore, need to ascertain the people's level of awareness of what constitutes hate speech in Nigeria, the effect of hate speech on victims as well as their opinion or reaction to some of the lists on the agenda of hate speech. It is believed that results obtained from data analysis would help government to draw appropriate plans that would help minimize people's use of hate speech and negative incidences that would result from it.

\section{Methodology and Theoretical Framework}

Data were elicited from the subjects through a structured questionnaire made up of four sections entitled: why people use hate speech, hate speech awareness, effects of hate speech and hate speech laws in Nigeria. The population comprised ninety members of the Abia State Polytechnic, Aba community: academic staff, non academic staff and students randomly selected. The research adopted simple percentage formulae for data analysis. The work is hinged on Austin's 1978 Speech Act Theory and Özarslan's (2014) Hate Act theory.

\section{Conceptual Clarifications}

Speech Act theory was credited to the Oxford Philosopher J.L. Austin who believes that sentences are not limited to the functions of making statements but can be used to perform other communicative functions such as asking questions, making requests or promises and many other functions. Austin also claims that some sentences are themselves a kind of action (Saeed, 2003, p.224). For instance when one says "I write letters" the statement involves the act of writing; it is a statement which embodies an act. Such and similar sentences are what Austin classifies as Performative utterances. Reviewing Austin's claims of the different functions of sentences, Saeed (2003) notes that sentences are classified into locutionary act which comprises the act of saying something that makes sense; illocutionary act which refers to the action intended by the speaker and perlocutionary act which refers to the effect of an illocutionary act. Although linguists are not so much interested in perlocutionary act as it falls outside linguistic description, hate speech in this case is viewed from both illocutionary and perlocutionary acts. In Nigeria and other parts of the world where hate speech is condemned, it is not as a result of its linguistic form but as a result of its effect on the people's well being and its threat to the unity of a nation.

\section{Hate speech}

Citing Neissser (1994, p.337), Alakali, Faga and Mbursa (nd, p.164) define hate speech as "all communications (whether verbal, written, symbolic) that insults a racial, ethnic and political group, whether by suggesting that they are inferior in some respect or by indicating that they are despised or not welcomed for other reasons." From the above definition, it means that hate speech refers to utterances against a group or race. For Weber (2009), hate speech refers to the "speech that attacks, threatens, or insults a person or group on the basis of national origin, ethnicity, colour, religion, gender, identity, sexual orientation or disability" (p.9). In Weber's definition, an individual can as well be a victim of hate speech, but on account of his association with or belonging to a particular group or colour or origin. Downs and Cowan (2012) note that hate speech is a dangerous weapon which is capable of demeaning the victim's ego, terrorizing, wounding and resulting in both mental and physical injury. In the same vein, Özarslan (2014,p.70) observes that hate speech is sometimes accompanied by violent acts against the other person hence he maintains that it is not just hate speech but also hate act. Özarslan's (2014) observation is in tandem with Austin's Perlocutionary act which shows that speeches do not only state but also acts. Butler (1994) declares that hate speech is a linguistic injury which produces similar effect as physical injury.

In Nigeria and in other parts of the world, hate speech is frowned at. It is viewed as being capable of initiating conflict or war as well as capable of causing psychological trauma which may result in physical combat or incite people to act in an inordinate manner. Although in Nigeria hate speech and hate speech laws seem to be a current phenomenon which started in 2017 when the Vice President, Prof. 
Yemi Osibanjo and the senate declared hate speech as illegal and an act of terrorism, hate speech laws have been in existence in Nigeria and in several international communities such as United Nations, the USA, Kenya, etc (Alakali, Faga, and Mbursa (nd). The above source further observes that hate speech laws have been in existence in cyber-space and political party codes in Nigeria. In addition, there exist some international laws on hate speech which includes members of the Nigerian society.

\section{Sustainable National Cohesion}

The chairman, committee on national cohesion and values of the Meru University of Science and Technology, Kenya defines cohesion "as a conscious desire for diverse groups of people to belong together and affirm the conditions of mutual dependence" (Amos, 2016). National cohesion, therefore, refers to a people's conscious capacity to work together towards harmonious co-existence. It involves the people defining methods of interaction at all facets of life, striving to work together and accommodating people from different cultures and ethnic groups. National cohesion also includes providing a level and fair ground with equal opportunities for people from diverse backgrounds.

Nigeria is as multi-cultural as it is multi-ethnic. One of the features of Nigeria's multi-ethnicity is multi-lingualism, and majority of the languages are not mutually intelligible. This situation gives rise to the "we" and "you' or "the other" syndrome which creates fractions, insecurity and the feeling of superiority/inferiority. Cohesion in the Nigerian context is a welcome development. There is need for the diverse ethnic groups to devise means of achieving a cohesive society which would ensure peaceful co-existence among the citizens, ethnic, political and religious groups and reduced gender disparity. One of the reasons for establishing cohesive programmes in a country is to prevent or reduce inter-ethnic violence or conflict, discrimination on the basis of race, ethnicity, sex or religion (Wikipedia, 2017; Amos, 2016). In addition, the agenda for a cohesive society would include sustainable development (Baba and Aeysinghe, 2017), maintenance of peace and order, enhancing security of life and property.

In Nigeria and in other parts of the world, hate speech has been identified as one of the factors that challenge a country's national unity. It does not only institute negative ethnicity and divisive ideologies but also is capable of instituting ethno-religious rivalry, communal conflicts, civil wars or inflicting psychological injury. It is based on this that the Nigerian government has found it necessary to promulgate laws against hate speech offenders as well as constitute a commission that would help combat the use hate speech in Nigeria.

\section{Data Presentation and Analysis}

The data presented in Tables I - 4 comprised the items in the questionnaire and summary of the respondents' responses on each item.

Table 1: Respondents Response on Why People Use Hate speech

\begin{tabular}{|c|c|c|c|c|c|c|c|}
\hline \multirow[t]{2}{*}{$\mathbf{S} / \mathbf{N}$} & \multirow[t]{2}{*}{ Questions } & \multicolumn{2}{|c|}{ Academic Staff } & \multicolumn{2}{|c|}{ Non-academic staff } & \multicolumn{2}{|c|}{ Students } \\
\hline & & $\begin{array}{l}\text { True } \\
\%\end{array}$ & $\begin{array}{c}\text { False } \\
\%\end{array}$ & $\begin{array}{l}\text { True } \\
\%\end{array}$ & False \% & $\begin{array}{l}\text { True } \\
\%\end{array}$ & False \\
\hline 1 & $\begin{array}{l}\text { People use hate speech because they hate other } \\
\text { ethnic groups }\end{array}$ & 63.3 & 36.7 & 33.3 & 66.7 & 33.3 & 66.7 \\
\hline 2 & $\begin{array}{l}\text { People use hate speech because they are facing } \\
\text { economic hardship }\end{array}$ & 66.7 & 33.3 & 90.0 & 10.0 & 46.7 & 53.3 \\
\hline 3 & $\begin{array}{l}\text { People use hate speech because the are } \\
\text { marginalised }\end{array}$ & 70.0 & 30.0 & 86.7 & 13.3 & 60.0 & 40.0 \\
\hline 4 & $\begin{array}{l}\text { Hate speech results from hate actions from } \\
\text { other groups }\end{array}$ & 70.0 & 30.0 & 86.7 & 13.3 & 43.3 & 56.7 \\
\hline 5. & $\begin{array}{l}\text { People use hate speech because they want to } \\
\text { demean others }\end{array}$ & 73.3 & 26.7 & 40.0 & 60.0 & 56.7 & 43.3 \\
\hline 6. & $\begin{array}{l}\text { People use hate speech because they want to } \\
\text { outwit others }\end{array}$ & 53.3 & 46.7 & 60.0 & 40.0 & 56.7 & 43.3 \\
\hline 7. & $\begin{array}{l}\text { People use hate speech because the } \\
\text { constitution guarantees freedom of speech }\end{array}$ & 16.7 & 88.3 & 50.0 & 50.0 & 46.7 & 53.3 \\
\hline
\end{tabular}

Source: Field research

The data on Table 1 show that $63.3 \%$ of academic staff respondents accepted that people use hate speech because they hate other ethnic groups while $33.3 \%$ of both non-academic and student respondents were of the view that hate speech 186 
does not result from hatred for other ethnic groups. On economic hardship and marginalisation, over $65 \%$ of both academic and non-academic respondents were of the opinion that people use hate speech as a result of economic hardship and marginalisation while $46.7 \%$ and $60 \%$ of the student respondents indicated that hate speech results from economic hardship and margnalisation respectively. Also, over $65 \%$ of academic and non-academic staff respondents were of the view that hate action from other groups is another source of hate speech while over $50 \%$ of the student respondents said hate speech does not result from hate action. Between 56.7\% and $73.3 \%$ of the entire respondents indicated that people use hate speech to demean others while between $53.3 \%$ and $60 \%$ of the respondents said people use hate speech in order to outwit others. Although the constitution guarantees freedom of speech, academic staff and student respondents said people do not use hate speech because the constitution guarantees freedom of speech while $50 \%$ of the non academic staff respondents indicated that people use hate speech because the constitution guarantees freedom of speech. This shows that the use of hate speech is not a deliberate abuse of freedom of speech as enshrined in article 38(1) of the Nigerian constitution (FRN, 1999) and international laws such as article 19 of the Universal Declaration of Human Rights (UDHR) of $10^{\text {th }}$ December, 1948 (Özarslan, 2014).

What the results in Table 1 reveal is that majority of the respondents were aware that people use hate speech and the reasons they do so. From the results, it was also discovered that over $65 \%$ of the respondents indicated that hate speech results from economic hardship, marginalisation, and the desire to demean and outwit others.

Table 2: Respondents Response on Hate Speech Awareness

\begin{tabular}{|c|c|c|c|c|c|c|c|}
\hline \multirow[t]{2}{*}{$\mathbf{S} / \mathbf{N}$} & \multirow[t]{2}{*}{ Questions } & \multicolumn{2}{|c|}{ Academic Staff } & \multicolumn{2}{|c|}{$\begin{array}{l}\text { Non-academic } \\
\text { staff }\end{array}$} & \multicolumn{2}{|c|}{ Students } \\
\hline & & $\begin{array}{l}\text { True } \\
\%\end{array}$ & $\begin{array}{c}\text { False } \\
\%\end{array}$ & $\begin{array}{l}\text { True } \\
\%\end{array}$ & $\begin{array}{l}\text { False } \\
\%\end{array}$ & $\begin{array}{l}\text { True } \\
\%\end{array}$ & False \\
\hline 1 & $\begin{array}{l}\text { I have been sufficiently informed of what } \\
\text { constitutes hate speech in Nigeria }\end{array}$ & 60.0 & 40.0 & 36.7 & 63.3 & 66.7 & 33.3 \\
\hline 2 & $\begin{array}{l}\text { I know the dangers involved in the use of } \\
\text { hate speech }\end{array}$ & 86.7 & 13.3 & 70.0 & 30.0 & 80.0 & 20.0 \\
\hline 3 & $\begin{array}{l}\text { People I know have complained against } \\
\text { hate speech }\end{array}$ & 76.7 & 23.3 & 73.3 & 26.7 & 73.3 & 26.7 \\
\hline 4 & $\begin{array}{l}\text { Hate speech contradicts the principles of } \\
\text { freedom of speech as enshrined in the } \\
\text { constitution }\end{array}$ & 50.0 & 50.0 & 73.3 & 26.7 & 73.3 & 26.7 \\
\hline 5. & $\begin{array}{l}\text { I have witnessed negative consequences } \\
\text { of hate speech in Nigeria }\end{array}$ & 63.3 & 36.7 & 86.7 & 13.3 & 66.7 & 33.3 \\
\hline 6 & $\begin{array}{l}\text { Hate speech is only illegal when used on } \\
\text { social media }\end{array}$ & 26.7 & 73.3 & 6.7 & 93.3 & 40.0 & 60.0 \\
\hline 7 & $\begin{array}{l}\text { Offline hate speech is not as injurious as } \\
\text { hate speech on social media }\end{array}$ & 50.0 & 50.0 & 83.3 & 83.3 & 63.3 & 36.7 \\
\hline 8 & $\begin{array}{l}\text { Offline hate speech is part of our speech } \\
\text { activity }\end{array}$ & 76.7 & 23.3 & 70.0 & 30.0 & 73.2 & 26.7 \\
\hline
\end{tabular}

Source: Field research

Table 2 presents the respondents' level of awareness on what constitutes hate speech. Over $50 \%$ of academic staff and student respondents indicated that they knew what constituted hate speech in Nigeria while over $60 \%$ of the nonacademic staff respondents said they did not know. Over $70 \%$ of the subjects accepted that they knew the dangers involved in the use of hate speech and have heard others complain against it. On the question if hate speech contradicts the principles of freedom of speech, about $50 \%$ of academic staff respondents said it does while over $70 \%$ of both nonacademic and student respondents said it does not. On witnessing the negative consequences of the use hate speech, over $60 \%$ of each set of the respondents said they have. Also, over $60 \%$ of the entire respondents indicated that hate speech is not limited to social media only which means that greater percentage of the respondents accepted that hate 
speech can be identified in other forms of interaction and communication. However, over $70 \%$ of all the respondents indicated that hate speech is part of our speech activity.

Table 3: Respondents Response on the Effects of Hate speech

\begin{tabular}{|c|c|c|c|c|c|c|c|}
\hline \multirow[t]{2}{*}{$\mathbf{S} / \mathbf{N}$} & \multirow[t]{2}{*}{ Questions } & \multicolumn{2}{|c|}{ Academic Staff } & \multicolumn{2}{|c|}{ Non-academic staff } & \multicolumn{2}{|c|}{ Students } \\
\hline & & $\begin{array}{l}\text { True } \\
\%\end{array}$ & $\begin{array}{c}\text { False } \\
\%\end{array}$ & $\begin{array}{l}\text { True } \\
\%\end{array}$ & False \% & $\begin{array}{l}\text { True } \\
\%\end{array}$ & False \\
\hline 1 & Hate speech promotes ethnicity in Nigeria & 73.3 & 26.7 & 36.7 & 63.3 & 56.7 & 43.3 \\
\hline 2 & $\begin{array}{l}\text { Hate speech does not affect national } \\
\text { unity/cohesion }\end{array}$ & 20.0 & 80.0 & 33.3 & 60.7 & 36.7 & 63.3 \\
\hline 3 & Hate speech encourages violence in Nigeria & 80.0 & 20.0 & 83.3 & 16.7 & 73.3 & 26.7 \\
\hline 4 & $\begin{array}{l}\text { Hate speech leads to under-development } \\
\text { Hate speech demeans people }\end{array}$ & 53.3 & 46.7 & 73.3 & 26.7 & 76.7 & 23.3 \\
\hline 6. & $\begin{array}{l}\text { Hate speech promotes 'we' and 'them' } \\
\text { syndrome }\end{array}$ & $\begin{array}{l}88.3 \\
80.0\end{array}$ & $\begin{array}{l}16.7 \\
20.0\end{array}$ & $\begin{array}{l}86.7 \\
73.3\end{array}$ & $\begin{array}{l}13.3 \\
26.7\end{array}$ & 63.3 & 36.7 \\
\hline 7. & Hate speech promotes hate actions & 80.0 & 20.0 & 93.3 & 6.7 & $\begin{array}{l}46.7 \\
53.3 \\
\end{array}$ & $\begin{array}{r}53.3 \\
46.7 \\
\end{array}$ \\
\hline
\end{tabular}

Source: Field research

The respondents were also tested on the effects of hate speech in Nigeria. Data collected showed that $36 \%, 56.7 \%$ and $73,3 \%$ of non-academic staff, student and academic staff respondents respectively accepted that hate speech promotes ethnicity in Nigeria. In support of the above, over $60 \%$ of each set of the respondents also accepted that hate speech affects national unity/cohesion. In the same vein, majority of them also indicated that hate speech encourages violence and leads to under-development. Similarly, over $60 \%$ of each set of respondents accepted that hate speech demeans people and promotes hate actions. From the above result, it is obvious that hate speech is a factor against sustainable national cohesion as well as a challenge to social and economic security. Nigeria is a multi-ethnic society; therefore any factor that promotes ethnicity will result in member citizens supporting ideologies that favour their group.

Table 4: Respondents Response on Hate speech Laws

\begin{tabular}{|c|c|c|c|c|c|c|c|}
\hline \multirow[t]{2}{*}{$\mathbf{S} / \mathbf{N}$} & \multirow[t]{2}{*}{ Questions } & \multicolumn{2}{|c|}{ Academic Staff } & \multicolumn{2}{|c|}{ Non-academic staff } & \multicolumn{2}{|c|}{ Students } \\
\hline & & $\begin{array}{l}\text { True } \\
\%\end{array}$ & $\begin{array}{c}\text { False } \\
\%\end{array}$ & $\begin{array}{l}\text { True } \\
\%\end{array}$ & False \% & $\begin{array}{l}\text { True } \\
\%\end{array}$ & False \\
\hline 1 & $\begin{array}{l}\text { Hate speech offenders in Nigeria should be } \\
\text { prosecuted }\end{array}$ & 46.7 & 53.3 & 73.3 & 26.7 & 53.3 & 46.7 \\
\hline 2 & $\begin{array}{l}\text { Death sentence is appropriate for hate speech } \\
\text { offense }\end{array}$ & Nil & 100 & Nil & 100 & 23.3 & 76.7 \\
\hline 3 & $\begin{array}{l}\text { I have been sufficiently informed of hate } \\
\text { speech laws }\end{array}$ & 26.7 & 73.3 & 23.3 & 76.7 & 16.7 & 88.3 \\
\hline 4 & $\begin{array}{l}\text { Government should formulate } \\
\text { appropriate hate speech laws }\end{array}$ & 88.3 & 16.7 & 83.3 & 16.7 & 66.7 & 33.7 \\
\hline 5. & $\begin{array}{l}\text { Offline hate speech should not be regarded as } \\
\text { an act of terrorism }\end{array}$ & 53.3 & 46.7 & 40.0 & 60.0 & 50.0 & 50.0 \\
\hline 6. & $\begin{array}{l}\text { Hate speech laws should cover both online } \\
\text { and offline hate speeches }\end{array}$ & 93.3 & 6.7 & 83.3 & 16.7 & 70.0 & 30.0 \\
\hline 7. & $\begin{array}{l}\text { Hate speech laws should covers hate actions as } \\
\text { well }\end{array}$ & 100 & Nil & 90.0 & 10.0 & 70.0 & 30.0 \\
\hline 8 & $\begin{array}{l}\text { Hate speech on social media only should be } \\
\text { prosecuted }\end{array}$ & 13.3 & 86.7 & 6.7 & 93.3 & 33.3 & 66.7 \\
\hline
\end{tabular}

Source: Field research 
On hate speech laws, over $50 \%$ of both student and non-academic respondents indicated that hate speech offenders should be prosecuted in Nigeria while 53.3\% of academic staff respondents rejected prosecution of the offenders. However, $100 \%$ of both academic and non-academic staff and $70 \%$ of student respondents indicated that death sentence is not the appropriate punishment for hate speech offenders. Over $60 \%$ of each set of respondents were of the view that government should formulate appropriate laws that would help control the use of hate speech in Nigeria. Their response shows that majority of the respondents believed that there should be laws on hate speech excluding death sentence penalty. In the same vein, over $70 \%$ of the entire respondents indicated that hate speech laws should cover both Offline and Online hate expressions. However, about 40\%, 50\% and 53.3\% of student, non-academic staff and academic staff respondents respectively said that offline hate speech should not be regarded as an act of terrorism. This shows that a significant number of them agreed that hate speech is negative but should not be treated as an act against the state or government.

\section{Hate Speech in Nigeria and its Implication on National Cohesion}

From data analysed and literatures reviewed, it is obvious that hate speech is the negative use of language both in social media and in other forms of communication. It is also observed that hate speech does not emanate on its own; there are some negative actions that generate manifestation of hate speech. For instance, on why people use hate speech, over $60 \%$ of each set of respondents were of the view that hate speech results from economic hardship, marginalisation and the desire to outwit others. Economic hardship results in greater percentage of the citizens living below the poverty line; marginalisation promotes ethnicity and widens the gap between and among different classes; the desire to demean and outwit the other also results from ethnicity and the syndrome of "we" and "them". All these factors are among the indicators of disunity; and when these indicators are on the increase, those at the receiving end would resort to hate speech since they lack other weapons to fight back.

From the data obtained from the respondents' level of awareness on existence and negative impact of hate speech in Nigeria, greater percentage of them accepted being sufficiently informed. However, a significant number still indicated being in the dark concerning the use of hate speech in Nigeria. For instance, over $60 \%$ of non-academic respondents indicated being unaware of what constitutes hate speech. Since hate speech laws are for everybody, there is need to set organized programmes that would sensitise the entire populace of government's plans on hate speech offenders.

On Table 3 which contains the respondents' response on the effect of hate speech, 20\%, 33.3\% and $36.7 \%$ of academic, non-academic staff and student respondents respectively indicated that hate speech has no effect on national unity/cohesion, but greater percentage of them showed that hate speech promotes "we" and "them" syndrome, hate action and violence in Nigeria. This shows that some of the respondents were not aware of some of the indicators of a non-cohesive society. Violence, hate actions and "we" and "them" syndrome are among the factors that challenge security and national cohesion; hence the issue of national cohesion should not end in research and other forms of documentation. This means that there is need to establish hate speech and national cohesion commission in Nigeria which would ensure that the people are educated on the indicators of and challenges on a cohesive society. Majority of the respondents also supported establishment of laws that would guide both online and offline hate speeches.

This is in agreement with article 10(2) of the European Council on Human Rights of $4^{\text {th }}$ November, 1950 which says that hate speech should be restricted for the interest of national security, public safety, territorial integrity, prevention of disorder or crime, etc (Özarslan, 2014).

\section{Conclusions}

This paper has established the presence and use of hate speech in Nigeria. Many of the respondents indicated that they have witnessed negative effects of hate speech in the Nigerian society. The work has also established that greater percentage of Abia State Polytechnic staff and students were aware of what constituted hate speech in Nigeria. They also supported establishing laws on hate speech but were against death sentence as the penalty for hate speech offence. Based on the above, this paper concludes that hate speech acts are among the factors that define a cohesive society and the programmes on hate speech and national cohesion should be taken seriously.

\section{Recommendations}

Based on findings from data analysis, the paper recommends as follows:

- Actions that could instigate hate speech such as maginalisation, factors that give rise to economic hardship and many others are to be monitored and curtailed in order to reduce incidences of psychological injury and frustration.

- Government needs to hasten its plan of setting up hate speech laws and a commission that would help in sensitizing people on hate speech and related matters.

- Hate speech laws on cyber-space and those in political party codes need to be enforced. However, it should consider people's opinion before passing the bill that recommends death sentence on hate speech offence. 


\section{References}

Alakali, T.T.; Faga, H.P. and Mbursa, J. (nd). Audience perception of hate speech and foul language in the social media in Nigeria: Implication for morality and law. In: Academicus International Scientific Journal

Amos, C. (2016). National cohesion and values. A paper presented by Amos Chege at student leaders induction workshop on national cohesion and values, at Meru University of Science and Technology, Kenya.

Baba, I. and Aeysinghe, C. (2017). Re-positioning Nigeria towards sustainable national unity, In: Global Journal of Human-social Science: Interdisciplinary, vol.17 (4). 41-49.

Butler, J. (1997). Excitable speech: A politics of the performative. New York: Routledge

Downs, D.M. and Cowan, G. (2012). Predicting the importance of freedom of speech and the perceived harm of hate speech. In: Journal of applied Social Psychology, Vol.42 (6),1353-1375

Federal Republic of Nigeria (1999). Constitution of the Federal Republic of Nigeria. Lagos: Federal Government Press.

Nyaruai, K. (2015). Factors affecting hate speech control for peace building in Kenyan social media: A case of Kenyan bloggers. M.A Dissertation submitted to Project Planning and Management, The University of Nairabi.

Saeed, J.I. (2007). Semantics. (2 $2^{\text {nd }}$ edition). Oxford, UK: Blackwell Publishing.

Özarslan, Z. (2014). Introducing two new terms into the literature of hate speech: "Hate Discourse" and "Hate Speech Act" application of "speech Act Theory" into hate speech studies in the era of Web 2.0 